\title{
THE FEDERAL RESERVE BANK
} of ST. LOUIS

\section{Selecting an Intermediate Target Variable for Monetary Policy When the Goal is Price Stability}

\author{
Michael T. Belongia \\ Dallas S. Batten
}

Working Paper 1992-008A

http://research.stlouisfed.org/wp/1992/92-008.pdf

\author{
FEDERAL RESERVE BANK OF ST. LOUIS \\ Research Division \\ 411 Locust Street \\ St. Louis, MO 63102
}

The views expressed are those of the individual authors and do not necessarily reflect official positions of the Federal Reserve Bank of St. Louis, the Federal Reserve System, or the Board of Governors.

Federal Reserve Bank of St. Louis Working Papers are preliminary materials circulated to stimulate discussion and critical comment. References in publications to Federal Reserve Bank of St. Louis Working Papers (other than an acknowledgment that the writer has had access to unpublished material) should be cleared with the author or authors.

Photo courtesy of The Gateway Arch, St. Louis, MO. www.gatewayarch.com 


\title{
SELECTING AN INTERMEDIATE TARGET VARIABLE FOR MONETARY POLICY WHEN THE GOAL IS PRICE STABILITY
}

\begin{abstract}
Conventional investigations of the "best" intermediate target variable for monetary policy have used a single criterion: the best fit between the behavior of an aggregate and that of some goal variable such as nominal spending or the aggregate price level. Ignored in this type of study, however, is the ability of the central bank to control the behavior of the aggregate which has the best fit relative to the goal variable. This paper treats the issue of monetary control explicitly and selects an intermediate target variable on the basis of a joint criterion of monetary control and relationship with the aggregate price level. The results indicate that all of the traditional simple sum aggregates perform poorly relative to Divisia aggregates or the currency-equivalent (CE) measure recently proposed by Rotemberg, et al.
\end{abstract}

KEYWORDS: $\quad$ Monetary Policy, Monetary Controls, Price Stability, Aggregate Price Level

JEL CLASSIFICATION: E51, E52

Michael T. Belongia

Federal Reserve Bank

411 Locust Street

St. Louis, MO 63166
Dallas S. Batten

Citibank, N.A.

55 Water Street, 43rd Floor, Zone 8

New York, NY 10041

Lynn D. Dietrich provided research assistance. William A. Barnett, James B. Bullard, Keith M. Carlson, K. Alec Chrystal, Michael J. Dueker, Michelle R. Garfinkel, Courtenay C. Stone and John A. Tatom provided many useful comments on an earlier draft of this paper. 
PERSONALDOCUMENTS $>$ MTB

SLCTNGIN.MTB

MTB : pd

$9 / 3 / 92$

Selecting An Intermediate Target For Monetary Policy When the Goal is Price Stability

\section{INTRODUCTION}

The number of independent objectives policymakers can achieve is less than or equal to the number of independent policy levers at their disposal. Because a central bank only has one policy lever--the quantity of reserves it supplies to the banking system--this constraint implies that it can (and should) pursue only one long run objective. Moreover, both economic theory and abundant empirical evidence suggest that, if a central bank is to choose the goal it is most likely to achieve, a goal based on the behavior of the aggregate price level is most appropriate. ${ }^{1}$ Perhaps in recognition of this constraint, recent public discussion and several legislative proposals have argued that the Federal Reserve should pursue price stability as its primary objective. ${ }^{2}$ And, based on results from various recent studies, the Federal Reserve has decided that targeting the behavior of $M 2$ is the best path at present for achieving that objective. Identifying a stable long-run relationship between a monetary aggregate and the price level, while necessary for a viable monetary policy process based on an intermediate target strategy, is not a sufficient condition for its success. ${ }^{3}$ Missing in virtually all discussions of which monetary aggregate might best suit a central bank's goals and procedures is evidence on whether the central bank can use its instruments to control the behavior of the aggregate. For example, in the specific case at hand, M2 may be the monetary aggregate with the best 
long-run relationship with the aggregate price level. But if the Fed lacks the tools to control its behavior, M2 cannot be used as an intermediate target variable. If this latter case were true, M2 would be better classified as an indicator variable, one which provides information about the thrust of monetary policy but cannot be used as an intermediate target because it cannot be controlled by central bank actions. ${ }^{4}$

In this paper we attempt to identify the "best" intermediate target variables for the Federal Reserve by dealing explicitly with the joint problem of which aggregates both can be controlled with some degree of precision by the central bank and still share a close enough relationship with aggregate price movements to make them useful in pursuing a goal of price stability. Financial innovations and regulatory changes during the 1980 s have complicated both elements of this issue. On the one hand, the reduction or elimination of reserve requirements on several broad asset categories have made the broader aggregates more difficult to control through open market operations. On the other hand, the introduction of interest-earning demand deposits has altered what had been, until the 1980s, stable relationships between narrow monetary aggregates and aggregate price movements. Our results indicate that the problem of controlling an intermediate target's behavior is sufficiently important to raise serious questions about the viability of the whole range of the traditional simple sum aggregates as intermediate target variables.

\section{THE EMPIRICAL PROBLEM}

An internediate target for monetary policy, as discussed above, must embody two features: it must share a close and predictable relationship with the central bank's policy objective and its behavior must be controllable by central bank actions. The literature on the first issue 
is vast and typically has tried to relate the behavior of monetary aggregates to nominal spending (GDP) or the inflation rate. Despite several decades worth of study, however, it is fair to say that no consensus has formed on the "best" intermediate target variable. Moreover, whatever enthusiasm had developed by the end of 1979 for the use of MI targeting was dissipated by the sharp and yet-unexplained shift in the trend of MI velocity in the 1980s.

Even in those recent cases where authors have reported a close correlation between a potential intermediate target and final goal variable, inferences about the potential usefulness of those targets have been limited because their controllability by the central bank has not been tested. And, in the few cases where controllability has been tested, (e.g. Belongia and Chalfant (1989)) the testing has occurred independently of tests for any relationship with the goal variables. As a result, these studies would not have addressed a point made by Andersen and Karnosky (1977): The choice of an intermediate target should depend on the overall error of an intermediate target strategy--control error plus projection error-rather than the two criteria evaluated sequentially. This total error is discussed in the next section and is used as our criterion for evaluating alternative intermediate targets.

\section{Combining Control and Projection Errors}

The logic of the Andersen-Karnosky argument is the following. In the two-step process of an intermediate target strategy, the central bank first must have an instrument of control. For our purposes, this instrument is taken to be the adjusted monetary base, which consists of currency in circulation and commercial bank reserves, and is adjusted for changes in reserve requirements. Although currency represents more than 
75 percent of the base, changes in the base are dominated by open market operations which influence the reserves component. Thus, even if currency demand changes, such a change can be offset over periods as long as a quarter (if that is deemed to be desirable) by an open market operation in the opposite direction. ${ }^{6}$

To repeat the argument and notation of Andersen and Karnosky, this control relationship can be written as:

(1) $\Delta 1 \mathrm{nM}=\Delta 1 \mathrm{~nm}+\Delta \operatorname{lnB}$

where $M=$ a monetary aggregate, $m=$ the money multiplier for the corresponding monetary aggregate and $\mathrm{B}=$ the adjusted monetary base. Even if the central bank can control the monetary base perfectly, the money multiplier changes over time such that achieving a target growth rate for a given monetary aggregate requires a forecast of expected movements in its multiplier. A forecast of the growth rate of the money multiplier $(\Delta I \mathrm{~nm})$ then has predicted and unpredicted elements, which can be expressed as:

(2) $\Delta \operatorname{lnm}=\Delta \operatorname{lnm}+\epsilon$, where $\Delta \mathrm{lnm}$ is the predicted growth rate and $\epsilon$ is the difference between the actual and predicted rates of growth. Inserting equation 2 into equation 1 then gives a revised monetary control equation of: (3) $\Delta \ln M=\Delta \ln B+\Delta \operatorname{lnm}+\epsilon$ where $\epsilon$ is the error in monetary control. 
The projection errors of an intermediate target strategy arise from differences between a predicted relationship of the intermediate target with the final goal variable and the actual behavior of the goal variable. For our chosen goal of controlling the rate of inflation and (for expositional ease) ignoring any lags in the target-goal relationship, we can write a projection equation of the form:

(4) $\Delta \ln P=a_{0}+a_{1} \Delta \ln M+u$

where $\mathrm{P}$ is the aggregate price level and $\mathrm{u}$ is the projection error. Still following Andersen and Karnosky, if we choose two different monetary aggregates (say, M1 and M2) as potential intermediate targets and employ them as the dependent variable in a control equat. on, such as equation 3, we can insert these two versions of equation 3 into equation 4 to yield:

(4a) $\Delta \ln P=a_{0}+a_{1} \Delta \operatorname{lnm} m_{1}+a_{1} \Delta \operatorname{lnB}+\left(a_{1} \epsilon_{1}+u_{1}\right)$

(4b) $\Delta \operatorname{lnP}=b_{0}+b_{1} \Delta \operatorname{lnm} m_{2}+b_{1} \Delta \operatorname{lnB}+\left(b_{1} \epsilon_{2}+u_{2}\right)$ where $\Delta \operatorname{lnm_{1}}$ and $\Delta l n n_{2}$ are, respectively, the predicted values of the growth rates of the M1 and M2 multipliers and the terms $\left(a_{1} \epsilon_{1}+u_{1}\right)$ and $\left(b_{1} \epsilon_{2}+u_{2}\right)$ are the total (control plus projection) errors associated with using these intermediate targets to pursue this particular monetary policy objective.

Within this specific framework, the "best" intermediate target variable among the candidates examined is that which produces the smallest total error. Andersen and Karnosky develop these arguments in more detail and discuss how, for example, M1 could be preferred to the adjusted monetary base as an intermediate target, even though the base 
can be controlled without error. ${ }^{7}$ Our interest in the next section, however, is to set forth and implement an empirical test for this general intuition.

SELECTING AMONG ALTERNATIVE INTERMEDIATE TARGETS

The eleven variables examined here as potential intermediate monetary targets are the adjusted monetary base (AMB), M1A, M1, M2, Divisia measures of MIA, M1 and M2, the currency equivalent (CE) money stock measure of Rotemberg, et al. (1991), both simple sum and Divisia measures of the "zero-maturity" money stock (MZM) proposed by Poole (1992) and an MIA measure constructed with the CE weights suggested by Rotemberg (1989) (CEMlA) ${ }^{8}$ Table 1 provides a listing of the asset composition of each aggregate.

The ten monetary aggregates examined (both simple sum and Divisia measures of M1A, M1, M2 and the CE and MZM measures) are various measures of the liabilities of depository institutions ranging from the very narrow (MIA) to the very broad (M2). The traditional view generally has been that the narrower monetary aggregates possess the characteristics best suited for use as an intermediate target. On one hand, narrow aggregates, which are composed primarily of demand deposits subject to reserve requirements, should be easier to control because the Fed's policy lever is bank reserves. On the other, narrow aggregates also should be more closely related to inflation because they are composed primarily of transactions deposits used to finance purchases of goods and services, while the broader aggregates contain a disproportionately large amount of savings deposits (or deposits with substantial savings characteristics), not generally used for transactions purposes. With the advent of financial deregulation and innovation during the 1980 s, 
however, these distinctions have become increasingly more clouded as potentially greater (less costly) substitutions among alternative deposit categories became available, changing both monetary control and the link between money and prices. Thus, the propriety of one aggregate over another has become even more of an empirical, rather than a conceptual, issue. ${ }^{9}$

The Empirical Framework

With the logic of the Andersen-Karnosky argument in mind, we sought to distinguish among the eleven competing potential intermediate targets in the following manner. First, we assumed that the adjusted monetary base can be controlled directly and without error by central bank open market operations, at least over the quarterly data interval adopted. For the remaining ten aggregates, whose behavior is influenced (rather than directly controlled) by open market operations, an equation was estimated to represent the link between those operations and the behavior of the target variables. This equation took the form of:

(5) $\dot{M}_{t}=a+\sum_{i=0}^{p} b_{i} * A \dot{M}_{t-i}+\sum_{j=0}^{q} c_{j} * \mathrm{~TB}_{t-j}+\epsilon_{t}$ where $\dot{M}_{t}$ is the growth rate of the candidate intermediate target, $\mathrm{AMB}$ is the growth rate of the adjusted monetary base and $\mathrm{TB}$ is the level of the three-month Treasury bill rate. The intercept coefficient (a) is an estimate of the average growth rate of the money multiplier and $b_{i}$ and $c_{j}$ are distributed lag coefficients estimated over some lag lengths, $p$ and $q$. Equation 5 represents the standard money multiplier model, which assumes that the central bank can control the behavior of the adjusted monetary base directly over periods as long as one qualtir and, by doing so, can affect the behavior of the monetary aggregates such as MIA, M1 and M2 with control error in period $t$ equal 
to the regression's residual, $\epsilon_{t}$. The Treasury bill rate was included as an additional variable in light of evidence provided by Gr rfinkel and Thornton (1991) on its effect on the money multiplier.

Equation 5 then was used to provide estimated values for the various monetary aggregates which, in turn, were used as arguments in equation 6 :

(6) $\dot{\mathrm{P}}_{\mathrm{t}}=\mathrm{c}_{0}+\sum_{j=0}^{\mathrm{q}} \mathrm{d}_{j} \dot{\mathrm{M}}_{\mathrm{t}-\mathrm{j}}+\sum_{\mathrm{m}=1}^{\mathrm{r}} \mathrm{k}_{\mathrm{m}} \dot{\mathrm{P}}_{\mathrm{t}-\mathrm{m}}+\xi_{\mathrm{t}}$ Equation 6, which represents a model of the inflation process, relates the growth rate of the GDP Deflator $\left(\dot{\mathrm{P}}_{\mathrm{t}}\right)$ to estimated current and past growth rates of some monetary variable $\left(\hat{\dot{M}}_{t-j}\right)$ and its own past behavior. Under the assumptions that (a) the central bank uses a monetary aggregate to pursue an objective for the inflation rate and (b) equation 6 is a reasonably accurate description of the actual inflation process, the use of estimated values (from equation 5) for the behavior of the various monetary aggregates should allow us to evaluate the performance of alternative intermediate targets by comparing the errors from all of the various estimates of equation 6 . That is, equation 6 , as estimated, embodies the control errors of equation 5 and the projection errors of equation 6 and is an empirical version of the Andersen-Karnosky framework.

This two-equation system was estimated by two-stage least squares for each aggregate over a sample of quarterly data spanning II/1965-I/1992; data from prior periods were exhausted on the relatively long lags for some monetary variables. As noted earlier, it was assumed that the adjusted monetary base can be controlled without error such that 
its actual growth rate was inserted as values for $\hat{\dot{M}}$ in equation 6 . For M1A, M1, M2, their three Divisia counterparts, and CE, MZM, DMZM and CEMIA, however, their estimated values from equation 5 were used when estimating equation 6 . The orders of the distributed lags $(q, r)$ were determined using a maximum length of 12 quarters in conjunction with Akaike's final prediction error (FPE) criterion. The individual equation results for both equations 5 and 6 are provided in Appendix tables 1 and 2.

The Test Statistic

The framework embodied in equations 5 and 6 to distinguish among alternative intermediate targets presents some problems for standard hypothesis testing because no version of equation 6 is nested in any of the other specifications. Consequently, comparisons between competing variables must be conducted using a method for testing non-nested hypotheses, such as the J-test developed by Davidson and Mackinnon (1981). This procedure establishes one specification of equation 6 as the null hypothesis and then tests whether an alternative specification using another intermediate target variable adds to the explanatory power of the specification under the null hypothesis.

In particular, assume that we want to test the specification, under the null $\left(\mathrm{H}_{0}\right)$

$$
H_{0}: y=f\left(x, z, \beta_{1}\right)+\epsilon_{1},
$$

against the alternative, $\left(\mathrm{H}_{1}\right)$

$$
\mathrm{H}_{1}: y=g\left(w, z, \beta_{2}\right)+\epsilon_{2} .
$$

The $J$-test is conducted simply by estimating

$$
y=(1-\phi) f\left(x, z, \beta_{1}\right)+\phi \hat{g}+\epsilon,
$$


where $\hat{g}$ is the vector of predicted $\mathrm{y}$ under the alternative hypothesis. The test is then whether $\varnothing$ is significantly different from zero using a conventional t-test. If the data are better fit to a model of the form $f\left(x, z, \beta_{1}\right)$, then $\phi$ should not be different from zero. Alternatively, if $\phi$ is different from zero, then the information from the model specified as $g\left(w, z, \beta_{2}\right)$ adds to the explanatory power of $f\left(x, z, \beta_{1}\right)$. The process is repeated by reversing the null and alternative hypotheses and repeating the same testing procedure. Such a procedure offers one of four possible outcomes: variable $\mathrm{X}$ contains more information than variable $Y$; variable $Y$ contains more information than variable $X$; each variable adds to the explanatory power of the other; or neither variable adds significantly to the information embodied in the other.

The qualitative results of the J-tests are shown in table 2; t-statistics for all of the pairwise comparisons are shown in Appendix table 3. The matrix cells indicate, of any two variable comparison, which of the two performed better in equation 6; as noted, the two possible indeterminate cases are denoted "B" (both variables added explanatory power) or "N" (neither had significant explanatory power). Beginning in the upper left corner of the matrix, the first five rows and columns present results only for simple sum measures, four of which are currently reported by the Federal Reserve. Limiting the discussion only to these data, the matrix entries show mostly indeterminate results; of the ten comparisons, only three show some distinction between pairs of aggregates. The new MZM measure, advanced by Poole, was judged to be superior both to MI and M2, the aggregate currently targeted by the Fed; it was not shown to embody more information relative to models based on MlA or the base, however. While the base appeared to possess more 
information than M1, the results at this level offer almost no guidance on the selection of an intermediate target variable. The primary implication from these results for monetary policy is that the Federal Reserve is correct when it expresses in recent statements concern over the usefulness of $M 2$ as a guide to policy. ${ }^{10}$

Looking at the bottom six rows of the matrix and only the first five columns from the left gives the results for comparisons between traditional simple sum measures currently reported and the various weighted monetary aggregates not currently reported or monitored. These results show both Divisia MIA and CEMIA to dominate all traditional measures; Divisia $M 2$ and $C E$ dominate all alternatives but the base. CEMIA, however, cannot be distinguished from MZM. The remaining results in this portion of the matrix show the base to be preferred in one comparison, but the general message is clear: Divisia and CE measures produce empirical results superior to those of the traditional simple sum measures. ${ }^{11}$

Finally, the lower right-hand portion of the matrix, encompassing the bottom six rows and last six columns, presents results for comparisons between the various weighted aggregates. While the previous discussion of simple sum $v$. weighted aggregates produced many clear distinctions, this portion of the table does not. Here, issues of broad v. narrow asset bundles are intermingled with two alternative index formulas and the results show no clear preference for a single aggregate. Divisia M2 seems to be better than its more narrow counterparts, but its information cannot be distinguished from that of an M1A measure constructed with CE weights. The broad CE aggregate, which is close to M2 in asset composition also dominates more narrow Divisia aggregates. Neither CE nor DM2, however, can be distinguished from CEM1A. The 
overall conclusion from this table would seem to be that one or more weighted aggregates could be used to pursue an intermediate target strategy aimed at achieving price stability but selecting a single candidate will require more study. In any event, however, the results offer strong evidence against the continued use of the traditional simple sum measures in policy formulation. ${ }^{12}$

SUMMARY AND CONCLUSION

In the conduct of monetary policy, the Federal Reserve typically has attempted to influence the behavior of an intermediate target variable to achieve some ultimate policy objective. Thus, the critical and necessary attributes of an intermediate target for monetary policy are that it have a predictable relationship with the ultimate goal of policy--stability of the aggregate price level in this study--and that it can be controlled by central bank actions.

A number of studies have made arguments in favor of a particular monetary aggregate based only on the criterion of its relationship with some final goal variable. On this basis, M2 has been selected as the Fed's intermediate target as well as its primary indicator variable. The results reported here indicate, however, that the central bank's ability to control the target also is crucial to an intermediate target strategy. Many of the broad monetary aggregates share virtually no relationship with the adjusted monetary base and, on this criterion alone, can be rejected as a candidate to serve as an intermediate target variable. This result has the practical implication that the focus on $\mathrm{M} 2$ during the past several years has been misplaced as portfolio substitutions, rather than central bank open market operations, apparently have been the primary factor in causing changes in its rate of growth. 
When potential intermediate targets are evaluated on the basis of their joint control and projection errors, the implication for monetary policy is that the Federal Reserve should focus on weighted monetary aggregates constructed with Divisia or CE weights. These measures are both controllable and associated closely with movements in the inflation rate. Although further research on the asset composition of an aggregate may lead to further improvements in results of this sort, the evidence here indicates that weighted monetary aggregates contain significantly more information for the conduct of monetary policy relative to their simple sum counterparts. 
Andersen, Leonall C. and Denis S. Karnosky. "Some Considerations in the Use of Monetary Aggregates for the Implementation of Monetary Policy," Federal Reserve Bank of St. Louis Review (September 1977), pp. $2-7$.

Barnett, William A. "The User Cost of Money," Economics Letters, Vo1. 1 (1978), pp. $145-49$.

- "Economic Monetary Aggregates: An Application of Index Number and Aggregation Theory, " Journal of Econometrics (September 1980), pp. $11-48$.

. "The Optimal Level of Monetary Aggregation," Journal of Money, Credit and Banking (November 1982, part 2), pp. 687-710.

"The Divisia Monetary Aggregates," in David Glasner (ed.), Encyclopedia of Business Cycles, Panics, Crises and Depressions, : Garland Publishing Co., forthcoming.

Barnett, William A., Douglas Fisher and Apostolos Serletis. "Consumer Theory and the Demand for Money," Journal of Economic Literature, (December 1992), forthcoming.

Barnett, William A., Melvin Hinich and Piyu Yue. "Monetary Policy with the Exact Rational Expectations Monetary Aggregates," in, Michael T. Belongia, ed. Monetary Policy on the 75 th Anniversary of the Federal Reserve System (Kluwer Academic Publishers, 1991a). Barnett, William A. "A Reply to Julio J. Rotemberg," in, Michael T. Belongia, ed. Monetary Policy on the 75 th Anniversary of the Federal Reserve System (Kluwer Academic Publishers, 1991b). 
Belongia, Michael T., and James A. Chalfant. "The Changing Empirical Definition of Money: Some Estimates from a Model of the Demand for Money Substitutes," Journal of Political Economy (April 1989), pp. $387-97$.

Bernanke, Ben S. "On the Predictive Power of Interest Rates and Interest Rate Spreads," New England Economic Review (November/December 1990), pp. $51-68$.

Boschen, John F. and Kathleen E. Talbot. "Monetary Base Growth, Deposit Growth, and Inflation in the Postwar United States," Journal of Business (July 1991), pp. 313-37.

Darby, Michael R., Angelo R. Mascaro and Michael L. Marlow. "The Empirical Reliability of Monetary Aggregates as Indicators: 1983-1987," Economic Inquiry (October 1989), pp. 555-85.

Davidson, R., and J. G. Mackinnon. "Several Tests for Model Specification in the Presence of Alternative Hypotheses," Econometrica 49 (May 1981), pp. 781-93.

Dwyer, Gerald P. Jr. and R.W. Hafer. "Is Money Irrelevant?" Federal Reserve Bank of St. Louis Review (May/June 1988), pp. 3-17.

Federal Reserve Bank of New York. Intermediate Targets and Indicators for Monetary Policy: A Critical Survey NY: Federal Reserve Bank of New York (1990).

Friedman, Benjamin M. and Kenneth N. Kuttner. "Money, Income, Prices, and Interest Rates," American Economic Review (June 1992), pp. $472-92$.

Garfinkel, Michelle R. "Commentary on 'Why Does the Fed Smooth Interest Rates?" in Michael T. Belongia, ed., Monetary Policy on the 75th Anniversary of the Federal Reserve System. Norwe11, MA: Kluwer Academic Publishers (1991). 
Garfinkel, Michelle R. and Daniel L. Thornton. "The Multiplier Approach to the Money Supply Process: A Precautionary Note," Federal Reserve Bank of St. Louis Review (July/August 1991), pp. 47-64. Greenspan, Alan S. "Statement to Congress on the Full Employment and Balanced Growth Act of 1978," July 21-22, 1992.

Hafer, R.W. and Dennis W. Jansen. "The Demand for Money in the United States: Evidence from Cointegration Tests" Journal of Money. Credit, and Banking (May 1991), pp. 155-68.

Hallman, Jeffrey J., Richard D. Porter and David H. Small. "Is the Price Level Tied to the M2 Monetary Aggregate in the Long Run?" American Economic Review (September 1991), pp. 841-58.

Hoskins, W. Lee. "Defending Zero Inflation: All for Naught," Federal Reserve Bank of Cleveland Economic Commentary (Apri1 1, 1991). Johannes, James M. and Robert H. Rasche. Controlling the Growth of Monetary Aggregates, Boston: Kluwer Academic Publishers (1987). Laidler, David. "The Quantity Theory is Always and Everywhere Controversial--Why?" Seminar Paper 89-03, Centre for International Economic Studies, University of Adelaide (July 1989).

Lucas, Robert E. "Two Illustrations of the Quantity Theory of Money," American Economic Review (December 1980), pp. 1005-14.

McCallum, Bennett $T$. "On Consequences and Criticisms of Monetary Targeting," Journal of Money, Credit and Banking (November 1985, part 2), pp. $570-97$.

Neal, Stephen L. "Legislation Regarding the Maintenance of Zero Inflation," 1991 House Joint Resolution 24, U.S. House of Representatives (January 3, 1991). 
Poole, William. "Where Do We Stand in the Battle Against Inflation?" in SOMC Policy Statement and Position Papers, PPS 92-01 Bradley Policy Research Center, William E. Simon Graduate School of Business Administration, University of Rochester (March 8-9, 1992). Rotemberg, Julio J., John C. Driscoll and James M. Poterba. "Money, Output, and Prices: Evidence from a New Monetary Aggregate," Working Paper No. 3326-91-EFA, Sloan School of Management, Massachusetts Institute of Technology (July 1991). 
1. See, for example, Lucas (1980) and Dwyer and Hafer (1988), who present evidence for a variety of countries that shows a close, one-to-one correspondence between the rate of money growth and the inflation rate.

2. See, among others, Neal (1991) and Hoskins (1991). It also has been argued in some contexts (e.g. Garfinkel (1991)) that reserve requirements may offer a second policy lever for the Fed. This possibility is not considered here.

3. This is not to say that an intermediate target strategy is viewed by everyone as the best set of procedures for a central bank to follow. See, for example, McCallum (1985) for a summary of criticisms and responses to those criticisms.

4. Another example of a variable in this class is the commercial paper Treasury bill rate spread which Bernanke (1990) and Friedman and Kuttner (1992) have found to be closely linked to economic activity; it has not been argued, however, that the Fed can control the behavior of this spread. For a comprehensive overview of intermediate targets for, and indicators of, monetary policy actions, their history in the United States and rationales for adopting or rejecting a particular target or indicator variable at a moment in time, see Federal Reserve Bank of New York (1990).

5. Indeed, as Laidler (1989) has argued, advocates of the Quantity Theory of Money have had substantial disagreements over time about the appropriate definition of "money" for empirical exercises. For example, within the past few years alone, authors have found evidence in favor of Divisia MlA (Belongia and Chalfant (1989)), simple sum MlA (Darby, et al. (1989)), M2 (Hallman, Porter and Small (1991), and Hafer and Jansen (1991)) and the currency equivalent (CE) aggregate of Rotemberg et al. (1991).

6. See, e.g., Johannes and Rasche (1987) for a discussion of the base and money stock control.

7. The argument depends on the existence and size of a negative covariance between the control erior and projection error; see their footnote 13, pp. 5-6. Also note the special case of the adjusted monetary base in this study: Although it is taken to be the Fed's instrument of control, other empirical evidence, (Boschen and Talbot (1991)), showing a close relationship with movements in the price level, also suggests it as an intermediate target. Thus, if it is dominated by another target variable, which is subject to some control error, it must be that the basic relationship with the price level has errors larger than the other variable's joint error or that the other variable produces a negative covariance between its control and projection errors which is sufficiently large to offset the effects of the two sources of error considered independently.

8. Measuring the money stock as Divisia or Fisher Ideal index numbers--rather than equally weighted sums of dollars in various asset categories--was proposed in Barnett (1980). Divisia weights are based on shares of expenditures on 
monetary services (Barnett (1978)). CE weights are calculated as:

$\frac{R_{t}-r_{i t}}{R_{t}}$ where $R_{t}$ is a benchmark rate of return and $r_{i t}$ is the return to the $i^{\text {th }}$ asset.

9. At another level, the Divisia and CE measures, which give smaller weights to individual assets as their own-rates of interest rise, are intended to mitigate these effects in broad measures such as M2.

10. See Greenspan (1992).

11. The CE measure, as proved in Barnett (1991b), also is the "true" economic stock of money in the sense that, under stationary expectations, it represents the discounted present value of the Divisia monetary service flow. Changing the assumption about expectations, however, also will affect the economic measure of the money stock.

12. Because the CE measures use 13 -month centered moving averages of the interest rate spreads used as weights, it was thought that this smoothing might be responsible for an artificially good fit against a relatively smooth series such as inflation. To investigate this possibility, unsmoothed series were constructed and compared but the qualitative results were unaffected. This may be the result of aggregating further to quarterly averages of monthly data for use in the estimation. 
Table 1

Asset Composition of Alternative Money Stock Measures

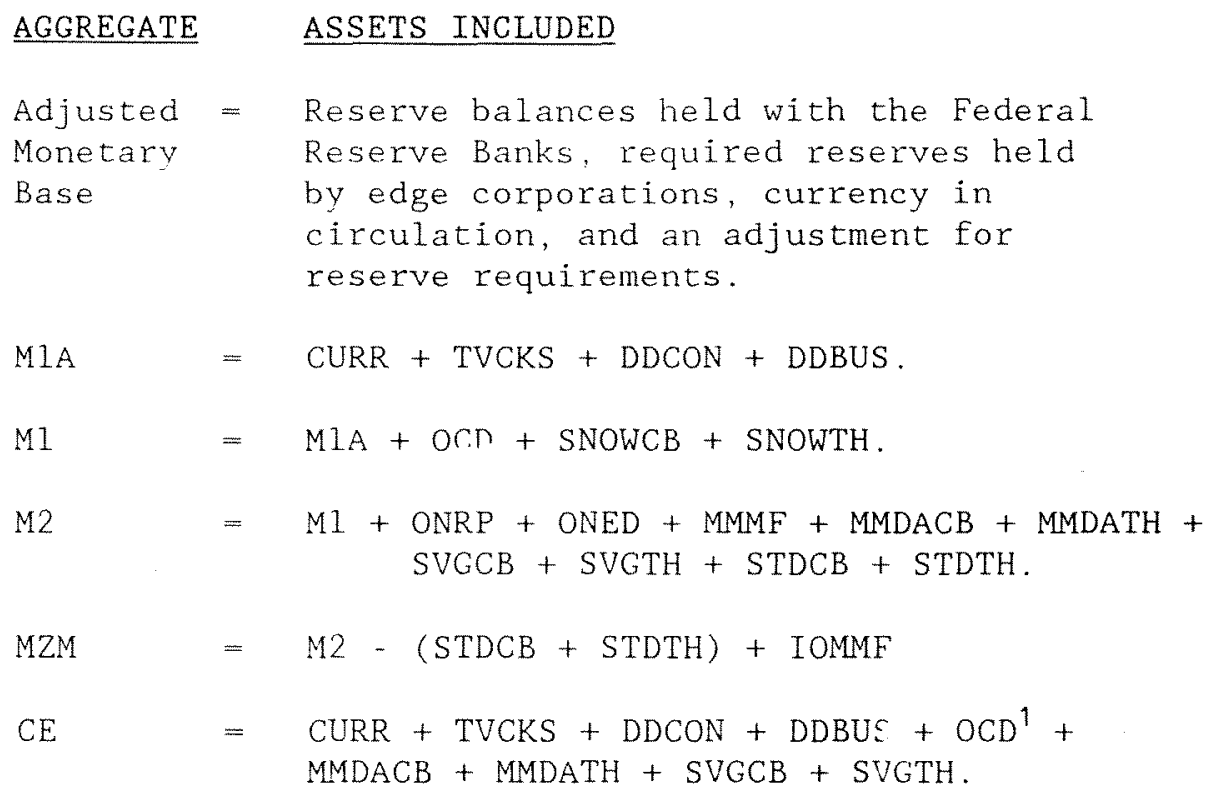

1/ The OCD series used to construct CE includes SNOWCB and SNOWTH.

CURR = Currency held by the nonbank public.

TVCKS = Traveler's checks.

DDCON = Demand deposits of consumers.

DDBUS = Demand deposits of businesses.

OCD = Other Checkable Deposits.

SNOWCB = Super NOW accounts at commercial banks.

SNOWTH = Super NOW accounts at thrifts.

ONRP = Overnight repurchase agreements.

ONED = Overnight eurodollar deposits.

MMMF = Money Market Mutual Funds.

MMDACB $=$ Money Market Demand Account Deposits at commercial banks

MMDATH = Money Market Demand Account Deposits at thrifts.

SVGCB = Savings deposits at commercial banks.

SVGTH = Savings deposits at thrifts.

STDCB = Small time deposits at commercial banks.

STDTH = Small time deposits at thrifts.

IOMMF = Institution-only Money Market Mutual Funds 
Table 2

Qualitative Results of J-Tests

\begin{tabular}{|c|c|c|c|c|c|c|c|c|c|c|c|}
\hline & AMB & $\underline{\mathrm{M} 1 \mathrm{~A}}$ & $\underline{M 1}$ & $\underline{M Z M}$ & $\underline{M 2}$ & $\underline{D M 1 A}$ & $\underline{\text { DM1 }}$ & $\underline{\mathrm{DMZM}}$ & $\underline{\text { DM2 }}$ & CEMIA & $\underline{\mathrm{CE}}$ \\
\hline$A M B$ & $\cdots$ & & & & & & & & & & \\
\hline MIA & $\mathrm{N}$ & - . & & & & & & & & & \\
\hline$M 1$ & $A M B$ & $\mathrm{~N}$ & & & & & & & & & \\
\hline MZM & B & B & MZM & .. & & & & & & & \\
\hline M2 & $\mathrm{N}$ & $\mathrm{N}$ & $\mathrm{N}$ & $M Z M$ & $\cdots$ & & & & & & \\
\hline DMIA & DMIA & DMIA & $\mathrm{DM} 1 \mathrm{~A}$ & DM1A & $D M \perp A$ & $\cdots$ & & & & & \\
\hline DM1 & AMB & $\mathrm{N}$ & $\mathrm{N}$ & MZM & $\mathrm{N}$ & $\mathrm{DM} \perp \mathrm{A}$ & $\cdots$ & & & & \\
\hline DMZM & B & B & $\mathrm{N}$ & MZM & $\mathrm{N}$ & DM1A & $\mathrm{N}$ & $\ldots$ & & & \\
\hline DM2 & B & DM2 & DM2 & DM2 & DM2 & DM2 & DM2 & DM2 & $\ldots$ & & \\
\hline CEMIA & CEM1A & CEM1A & CEM1A & B & CEM1A & B & CEMIA & B & B & $\ldots$ & \\
\hline$C E$ & B & $C E$ & $\mathrm{CE}$ & $\mathrm{CE}$ & $\mathrm{CE}$ & B & $C E$ & $\mathrm{CE}$ & B & B & $\ldots$ \\
\hline
\end{tabular}


Appendix Table 1

Results for Money Equation in the System Estimation Quarterly, 1965Q2-1992Q1

(coefficient sum, t-statistic, lag length)

\begin{tabular}{|c|c|c|c|c|}
\hline $\begin{array}{l}\text { Monetary } \\
\text { Aggregate }\end{array}$ & Constant & $\underline{A M B}$ & TB3 & $\underline{\bar{R}}^{2}$ \\
\hline $\mathrm{M} 1 \mathrm{~A}$ & $\begin{array}{c}3.08 \\
(2.04)\end{array}$ & $\begin{array}{c}1.08 \\
(5.44) \\
(0-5)\end{array}$ & $\begin{array}{c}-0.86 \\
(7.83) \\
(0.4)\end{array}$ & .63 \\
\hline MI & $\begin{array}{l}-2.63 \\
(1.71)\end{array}$ & $\begin{array}{c}1.20 \\
(5.94) \\
(0-5)\end{array}$ & $\begin{array}{c}0.10 \\
(0.85) \\
(0-5)\end{array}$ & .53 \\
\hline MZM & $\begin{array}{l}-2.94 \\
(1.04)\end{array}$ & $\begin{array}{c}0.59 \\
(1.70) \\
(0-1)\end{array}$ & $\begin{array}{c}0.85 \\
(3.46) \\
(0-6)\end{array}$ & .55 \\
\hline M2 & $\begin{array}{c}4.69 \\
(3.21)\end{array}$ & $\begin{array}{c}0.45 \\
(2.87)\end{array}$ & $\begin{array}{c}-0.02 \\
(0.14) \\
(0-2)\end{array}$ & .16 \\
\hline DMIA & $\begin{array}{l}3.97 \\
(3.25)\end{array}$ & $\begin{array}{c}0.83 \\
(6.14)\end{array}$ & $\begin{array}{c}-0.64 \\
(5.88) \\
(0-4)\end{array}$ & .57 \\
\hline DM1 & $\begin{array}{l}-0.13 \\
(0.11)\end{array}$ & $\begin{array}{c}0.82 \\
(6.45)\end{array}$ & $\begin{array}{c}0.15 \\
(1.46) \\
(0-4)\end{array}$ & .46 \\
\hline DMZM & $\begin{array}{c}1.64 \\
(0.93)\end{array}$ & $\begin{array}{c}0.74 \\
(3.43) \\
(0-1)\end{array}$ & $\begin{array}{c}-0.14 \\
(0.90) \\
(0-6)\end{array}$ & .70 \\
\hline DM2 & $\begin{array}{c}5.94 \\
(4.78)\end{array}$ & $\begin{array}{c}0.50 \\
(3.63)\end{array}$ & $\begin{array}{c}-0.47 \\
(4.21) \\
(0-4)\end{array}$ & .54 \\
\hline CEMIA & $\begin{array}{c}3.54 \\
(5.08)\end{array}$ & $\begin{array}{c}0.79 \\
(9.93)\end{array}$ & $\begin{array}{c}-0.39 \\
(5.79) \\
(0-8)\end{array}$ & .61 \\
\hline$C E$ & $\begin{array}{c}1.25 \\
(0.17)\end{array}$ & $\begin{array}{c}2.86 \\
(3.43) \\
(0-1)\end{array}$ & $\begin{array}{c}-2.32 \\
(3.95) \\
(0-3)\end{array}$ & .40 \\
\hline
\end{tabular}

Note: t-statistics are for $H_{0}: \sum A M B=0$ and $H_{0}: \sum$ TB3 $=0$. 
Appendix Table 2

Results for Inflation Equation in the System Estimation, Quarter1y 1965Q2-1992Q1 (cofficient sum, t-statistic, lag length)

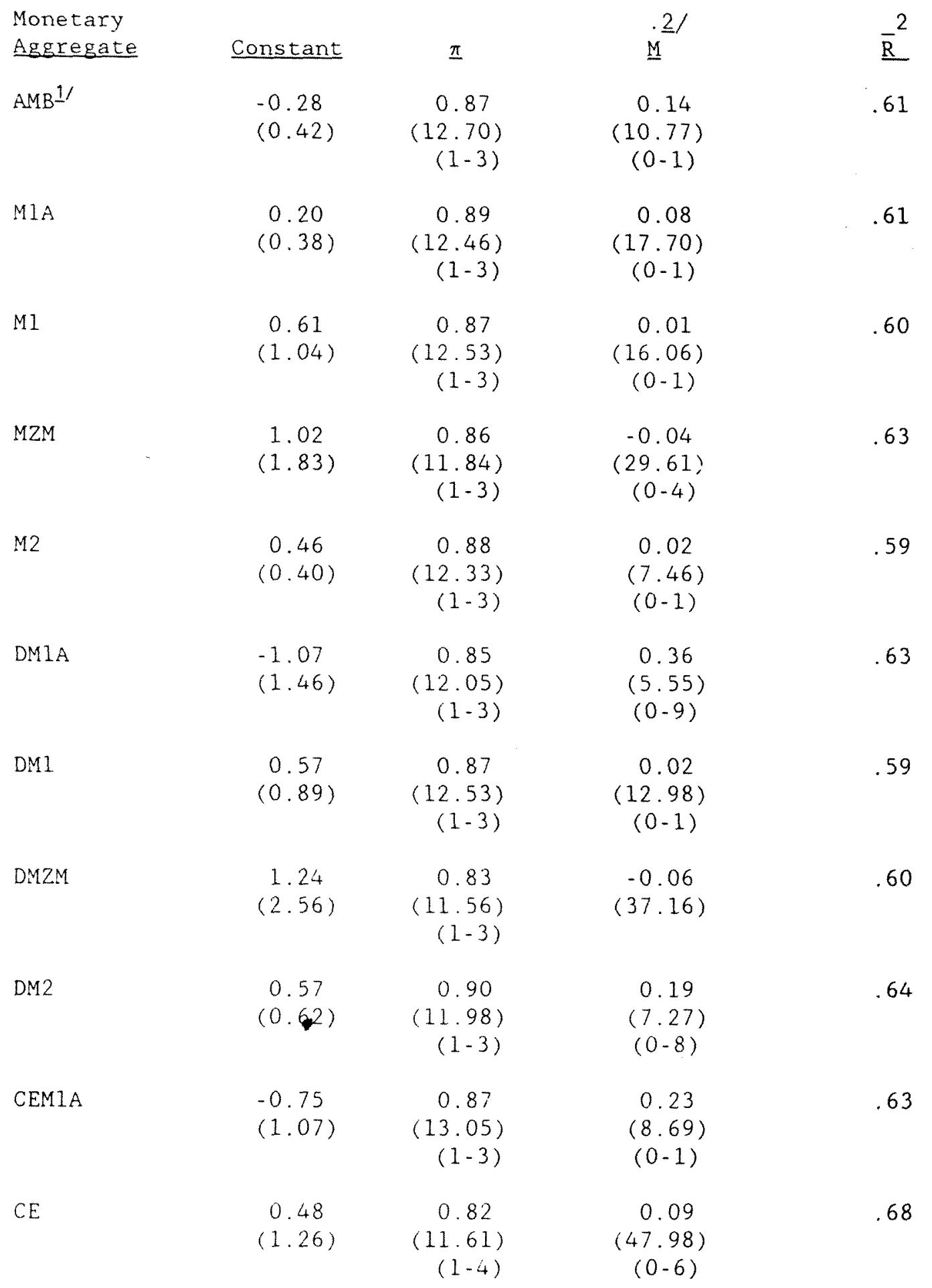

1) Results for AMB are from OLS estimations of the inflation equations above.

2f Null hypothesis for $\dot{M}$ is $H_{0}: \dot{\Sigma M}=1$. 
Appendix Table 3

Quantitative Results of J-tests ${ }^{1 /}$

\begin{tabular}{|c|c|c|c|c|c|c|c|c|c|c|c|}
\hline & $\underline{A M B}$ & $\underline{\mathrm{M} A \mathrm{~A}}$ & $\underline{\mathrm{Ml}}$ & $\underline{M Z M}$ & $\underline{\text { M2 }}$ & DMIA & $\underline{D M 1}$ & $\underline{D M Z M}$ & $\underline{\text { DM2 }}$ & CEM1A & $\underline{C E}$ \\
\hline$A M B$ & $\cdots$ & & & & & & & & & & \\
\hline WIA & $\begin{array}{l}0.669 \\
0.797\end{array}$ & $\cdots$ & & & & & & & & & \\
\hline MI & $\begin{array}{l}0.619 \\
2.482\end{array}$ & $\begin{array}{l}0.381 \\
1.287\end{array}$ & $\ldots$ & & & & & & & & \\
\hline MZM & $\begin{array}{l}4.229 \\
3.356\end{array}$ & $\begin{array}{l}3.549 \\
1.963\end{array}$ & $\begin{array}{l}3.508 \\
0.584\end{array}$ & $\ldots$ & & & & & & & \\
\hline M2 & $\begin{array}{l}0.827 \\
1.918\end{array}$ & $\begin{array}{l}0.781 \\
1.356\end{array}$ & $\begin{array}{l}0.577 \\
0.142\end{array}$ & $\begin{array}{l}0.625 \\
3.551\end{array}$ & $\ldots$ & & & & & & \\
\hline DM1A & $\begin{array}{l}4.299 \\
1.602\end{array}$ & $\begin{array}{r}4.025 \\
-0.562\end{array}$ & $\begin{array}{r}4.144 \\
-0.257\end{array}$ & $\begin{array}{l}2.869 \\
1.880\end{array}$ & $\begin{array}{l}4.244 \\
0.163\end{array}$ & $\cdots$ & & & & & \\
\hline DM1 & $\begin{array}{l}0.123 \\
2.631\end{array}$ & $\begin{array}{l}0.184 \\
1.429\end{array}$ & $\begin{array}{r}-0.268 \\
0.290\end{array}$ & $\begin{array}{l}0.858 \\
3.891\end{array}$ & $\begin{array}{r}-0.100 \\
0.704\end{array}$ & $\begin{array}{r}-0.255 \\
4.345\end{array}$ & $\ldots$ & & & & \\
\hline DMZM & $\begin{array}{l}2.651 \\
2.623\end{array}$ & $\begin{array}{l}2.387 \\
2.229\end{array}$ & $\begin{array}{l}1.253 \\
0.732\end{array}$ & $\begin{array}{r}-0.119 \\
3.043\end{array}$ & $\begin{array}{l}1.810 \\
0.752\end{array}$ & $\begin{array}{l}1.305 \\
4.333\end{array}$ & $\begin{array}{l}1.721 \\
0.703\end{array}$ & $\ldots$ & & & \\
\hline DM2 & $\begin{array}{l}4.659 \\
2.031\end{array}$ & $\begin{array}{l}4.334 \\
1.430\end{array}$ & $\begin{array}{r}4.247 \\
-0.526\end{array}$ & $\begin{array}{l}2.435 \\
0.505\end{array}$ & $\begin{array}{l}4.385 \\
0.208\end{array}$ & $\begin{array}{l}2.217 \\
1.574\end{array}$ & $\begin{array}{r}4.535 \\
-0.050\end{array}$ & $\begin{array}{l}4.234 \\
0.496\end{array}$ & $\ldots$ & & \\
\hline CEM1A & $\begin{array}{r}2.999 \\
-1.849\end{array}$ & $\begin{array}{r}2.800 \\
-1.244\end{array}$ & $\begin{array}{l}3.830 \\
0.092\end{array}$ & $\begin{array}{l}4.076 \\
3.721\end{array}$ & $\begin{array}{l}4.457 \\
0.361\end{array}$ & $\begin{array}{l}3.042 \\
3.458\end{array}$ & $\begin{array}{r}3.900 \\
-0.392\end{array}$ & $\begin{array}{l}3.731 \\
2.706\end{array}$ & $\begin{array}{l}3.446 \\
3.990\end{array}$ & $\ldots$ & \\
\hline$C E$ & $\begin{array}{l}6.043 \\
2.607\end{array}$ & $\begin{array}{l}5.874 \\
1.612\end{array}$ & $\begin{array}{l}5.839 \\
0.344\end{array}$ & $\begin{array}{l}4.863 \\
1.449\end{array}$ & $\begin{array}{l}6.082 \\
0.819\end{array}$ & $\begin{array}{l}4.888 \\
2.117\end{array}$ & $\begin{array}{l}6.100 \\
0.789\end{array}$ & $\begin{array}{r}5.716 \\
-0.097\end{array}$ & $\begin{array}{l}4.592 \\
1.997\end{array}$ & $\begin{array}{l}5.592 \\
2.585\end{array}$ & $\cdots$ \\
\hline
\end{tabular}

1/ The top entry in each cell is the t-statistic associated with the null hypothesis concerning the marginal information content of the row variable; the bottom entry applies to the marginal information of the column variable. 